\title{
Klatskin's cholangiocarcinoma presenting with the sign of Leser-Trelat
}

\author{
Ari Morgenthau, Abdulaziz Almudaires
}

Department of Medicine, Dalhousie University, Halifax, Nova Scotia, Canada

Correspondence to Dr Ari Morgenthau; a.morgenthau@dal.ca

Accepted 12 October 2019

\section{DESCRIPTION}

A female smoker in her seventies, presented to an emergency department with months of progressive weight loss, 1 week of worsening jaundice, pale stools and recent onset of episodic abdominal pain. Physical exam was notable for numerous seborrheic keratosis throughout the entire torso, ranging up to $\sim 2 \mathrm{~cm}$ in size (figure 1 panel A). As seen in the accompanying figure the lesions ranged from a pale fleshy pink colour to darkly pigmented. The lesions occurred suddenly over the last 3 months erupting diffusely over her body. A triphasic CT was performed, identifying severe intrahepatic biliary ductal dilatation with an isodense poorly enhancing slightly heterogeneous ill-defined $2.7 \times 2.2 \mathrm{~cm}$ mass at the confluence of the main intrahepatic ducts (figure 1 panel B arrows). The radiological diagnosis of Klatskin's cholangiocarcinoma, was supported by an elevated CA $19-9(48.7 \mathrm{U} / \mathrm{mL}) .{ }^{1}$ The obstruction was relieved with endoscopic retrograde cholangiopancreatography (ERCP); however, suitable tissue for pathological confirmation was not obtainable. This patient opted for palliative care, and sadly passed away months later.

This epithelial cell tumour typically have minimal and non-specific symptoms, therefore presenting with advanced disease. ${ }^{2}$ This patient's initial eruptions of numerous seborrheic keratosis, is consistent with the rare exam finding 'The Sign of Leser-Trelat' (figure 1 panel A). This poorly understood exam finding, first described in the 1900 s is an external manifestation

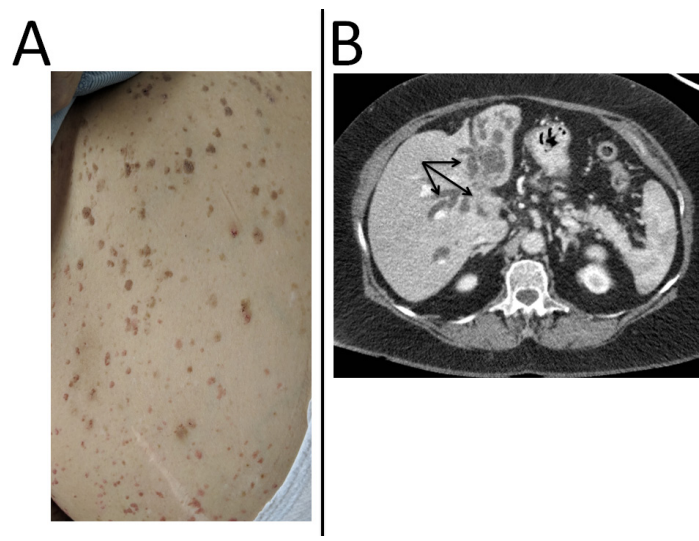

Figure 1 (A) Picture of patient's abdomen on presentation demonstrating an example of the seborrheic keratosis of varying pigmentation consistent with the physical exam finding 'The Sign of Leser-Trelat'. (B) A section of a triphasic CT using black arrows to highlight the isodense poorly enhancing slightly heterogeneous ill-defined mass consistent with cholangiocarcinoma.

\section{Learning points}

- The sign of Leser-Trelat is defined as the sudden eruption of of numerous, often multipigmented, seborrheic keratosis and should not be overlooked as a benign dermatological condition.

- The sign of Leser-Trelat is a paraneoplastic syndrome often associated with adenocarcinoma of the gastrointestinal tract and lung, and less commonly with hematological malignancies.

- While cholangiocarcinoma often presents late in its disease course, due to vague symptoms, in a rare subset of cases it manifests with paraneoplastic symptoms.

of internal malignancy, most commonly gastrointestinal adenocarcinomas and rarely with cholangiocarcinoma. ${ }^{3-5}$ It is hypothesised that the eruptions are the results of cytokines and growth factors, such as epidermal growth factor alpha, produced by neoplastic cells. ${ }^{6}$ Despite controversy regarding the utility of the sign of Leser-Trelat given the prevalence of benign seborrheic keratosis with age, patient's presenting with rapid widespread development of seborrheic keratosis, such as ours, should have occult malignancy on the differential. Notably with confirmed cases, the eruptions will often resolve with response to therapy of the underlying malignancy.

Contributors $\mathrm{AM}$ and $\mathrm{AA}$ contributed equally to the preparation of this manuscript.

Funding The authors have not declared a specific grant for this research from any funding agency in the public, commercial or not-for-profit sectors.

Competing interests None declared.

Patient consent for publication Obtained.

Provenance and peer review Not commissioned; externally peer reviewed.

\section{REFERENCES}

1 McNally PR. GI/Liver secrets plus E-Book. Elsevier Health Sciences, 2010.

2 Squadroni M, Tondulli L, Gatta G, et al. Cholangiocarcinoma.. Crit Rev Oncol Hematol 2017;116:11-31.

3 Holländer E, Darmcarcinoms BzurFdes. Hereditätsverhältnisse und Hautveränderungen). DMW-Deutsche Medizinische Wochenschrift 1900;26:483-5.

4 Mendes GB, Zanetti G, Marchiori E. Leser-Trélat sign secondary to thymic carcinoma. Arch Bronconeumol 2018;54:286-7.

5 Scully C, Barrett WA, Gilkes J, et al. Oral acanthosis nigricans, the sign of Leser-Trélat and cholangiocarcinoma. Br J Dermatol 2001;145:506-7.

6 Heaphy MR, Millns JL, Schroeter AL. The sign of Leser-Trélat in a case of adenocarcinoma of the lung. J Am Acad Dermatol 2000;43:386-90. 
Copyright 2019 BMJ Publishing Group. All rights reserved. For permission to reuse any of this content visit https://www.bmj.com/company/products-services/rights-and-licensing/permissions/

BMJ Case Report Fellows may re-use this article for personal use and teaching without any further permission.

Become a Fellow of BMJ Case Reports today and you can:

- Submit as many cases as you like

- Enjoy fast sympathetic peer review and rapid publication of accepted articles

Access all the published articles

Re-use any of the published material for personal use and teaching without further permission

Customer Service

If you have any further queries about your subscription, please contact our customer services team on +44 (0) 2071111105 or via email at support@bmj.com.

Visit casereports.bmj.com for more articles like this and to become a Fellow 